Civil Engineering

Volume 170 Issue CE6

Crossrail project: finance, funding and value capture for London's new Elizabeth line

Buck
Proceedings of the Institution of Civil Engineers Civil Engineering 170 November 2017 Issue CE6 Pages 15-22 http://dx.doi.org/10.1680/jcien.17.00005 Paper 1700005

Received 06/02/2017 Accepted 19/06/2017 Keywords: government/local government/public policy i

\title{
Crossrail project: finance, funding and value capture for London's Elizabeth line
}

Martin Buck FICE FRICS

Director, Crossrail Limited (2003-2016), London, UK

The $\mathbf{f 1 4 . 8}$ billion Crossrail project to deliver the new Elizabeth line east-west railway across London is the UK's largest transport project. Getting it into reality was only possible through an innovative programme of finance, funding and value capture, which saw London business and future passenger revenues contribute approximately two thirds of the cost. This paper sets out the experience and lessons learned from the funding structure established to enable the Crossrail project to proceed.

\section{Introduction}

At the outset of the establishment of the Crossrail project to deliver the new Elizabeth line east-west railway across London, the UK government's preferred delivery model was a privately financed concession. When this proved to be unachievable the Treasury capped the contribution from the central exchequer at around a third of the overall cost, requiring the remaining funding to be generated from the 'beneficiaries' of the project.

The Department for Transport (DfT) and Transport for London (TfL) - together the 'sponsors' - collaborated with the business and property development communities in London to assemble a finance and funding package. The quality of the cost estimate together with the confidence generated by the risk analysis enabled the sponsors to make the political and financial commitments necessary.

In turn, the certainty of funding provided the project company with a high level of financial stability and covenant to proceed and sustain the project.

\section{Background}

Following the Second World War, London's population shrank from a peak of around 8.6 million to a low point of 6.7 million in the early 1990 s - a $22 \%$ fall. The population then recovered rapidly through the following decade, subsequently surpassing the previous high, reaching 8.7 million in 2015 . The combined effect of the growing population and strong economic performance of the professional and financial services industries elevated Crossrail from a long-standing aspiration to a necessity.

Following a failed attempt to promote Crossrail in the 1990s, Cross London Rail Links Ltd (CLRL) was formed in 2002 to develop new proposals (Figure 1). CLRL was a legally separate vehicle initially owned on a 50:50 basis by the Strategic Rail Authority (SRA) (succeeded by DfT directly) and TfL. While CLRL's main function at that point was to support the preparation of the parliamentary hybrid bill to provide the powers for the project, CLRL was also tasked with developing options for delivery of the project.

CLRL engaged financial adviser Bank of America and legal adviser Ashurst and undertook a wide-ranging review of the funding and finance options and delivery models available. The resulting Crossrail Business Case (CLRL Ltd, 2003) was presented to the then Secretary of State for Transport, Alistair Darling, in July 2003.

He announced that the government supported the principle of a new east-west Crossrail link, but wanted to be assured that CLRL's proposal was deliverable and financeable. He appointed a review team, led by Adrian Montague (formerly deputy chairman

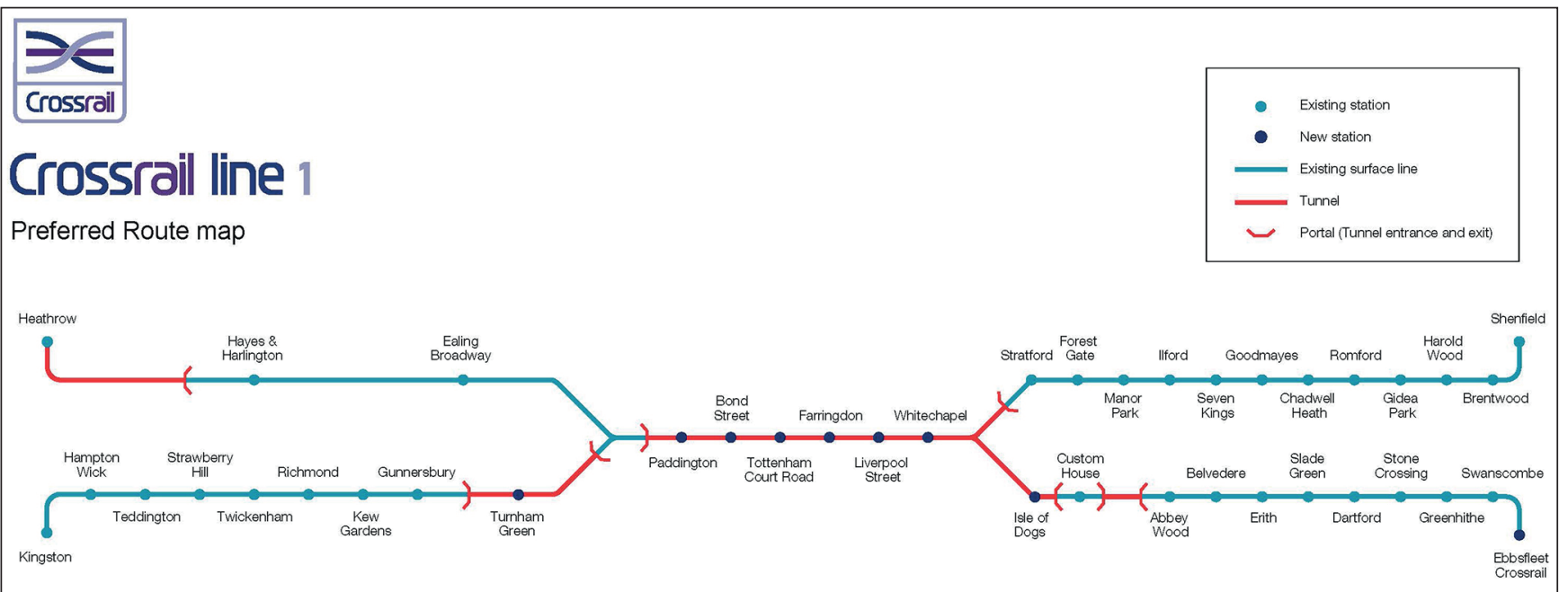

Figure 1. 2003 Preferred route 
of Network Rail and chief executive of the Treasury Taskforce), to assess this.

The Crossrail Review published in July 2004 (Montague, 2004) set out a number of findings, noting that the scheme was expected to cost in the region of $£ 10$ billion at the first quarter of 2003 prices - approximately $£ 17$ billion nominal outturn - which it considered to be 'acceptable value for money'. Significantly on funding, the report also noted 'doubt as to the available market capacity in the construction and financial sectors to support a project of this size' (Montague, 2004: p. 2).

The report though went on to note, 'London business interests appear ready to contribute significant amounts, in the range of $£ 2000$ million to perhaps $£ 3000$ million NPV [net present value], to the project by way of Alternative Funding Mechanisms' (Montague, 2004: p. 2). This indication of substantial contribution from business sources proved to be a pivotal moment in the funding case for Crossrail. It had crossed the threshold from why should the project be undertaken to how and when.

The significant question of how such a contribution could be realised and whether it would be sufficient to bridge the substantial funding gap still remained, with Darling noting in his written statement to parliament that, 'a major funding challenge remains' (Hansard, 2004: col. 23WS) and that, 'those who benefit from Crossrail should contribute substantially to its delivery' (Hansard, 2004: col. 24WS).

It was clear from the Crossrail Business Case and the Crossrail Review that the scale of the project was too great (and potentially too complex) for a conventional privately financed solution. CLRL therefore commissioned a second report, this time from legal advisors Ashurst, Royal Bank of Scotland, and insurance brokers and risk assessors Marsh, to establish a more detailed business model through which CLRL (as delivery vehicle on behalf of DfT and TfL) would propose to act as the delivery vehicle for the project on a principally public procured (as opposed to private-finance initiative) solution.

The business model published in 2004 effectively established the blueprint for an empowered, publicly owned quasi-independent delivery vehicle for the project. This was a relatively novel approach at the time. In due course, CLRL became the nominated undertaker vested with the statutory powers to undertake the scheme, and with the transfer of $100 \%$ ownership to TfL in December 2008, a formal governance structure and legal arrangements for a successor company, Crossrail Ltd (CRL), were put in place reinforcing its powers and quasi-independent status as a subsidiary of TfL.

It remained for the sponsors to crystallise the case for such a large investment, and in July 2006 the Greater London Authority (GLA) and TfL set out the case for investment based on growth, productivity gains assessed around the context of the agglomeration effects of additional transport provision.

CRL and the sponsors worked with the government and respective stakeholders to reduce the cost of the project by around $£ 2$ billion and assemble a funding structure endorsed in the government's comprehensive spending review of 2007. Further background is available on the Crossrail Learning Legacy website (Crossrail, 2017).

\section{Political and stakeholder support}

As with any public investment of such a large-scale, political support was imperative. The main political champion for the project was the then mayor of London, Ken Livingstone, with the senior management team at TfL.

The office of Mayor of London was created with the GLA in 2000. Following the abolition of the Greater London Council in 1986 London had been administered by a range of joint boards and other government agencies, and it is arguable that without the single point focus provided by the office of mayor the arrangements put in place to enable the Crossrail project would not have been possible.

The mayor's office together with TfL coordinated the case for the Crossrail project. While the project had a positive 2:1 ratio on the public sector's traditional cost-benefit analysis calculation, the mayor's chief economic adviser Bridget Rosewell was instrumental in developing that case into a commercial vision for business in London. That in turn, coupled with the close involvement of London First, an influential business-based lobby group, resulted in an unprecedented level of involvement of the business community in the promotion of the project.

According to Rosewell (personal communication), 'The case for Crossrail had to be made by a wide variety of stakeholders, from business interests to local communities. It also needed to be accepted by the Treasury and the DfT, and the acceptance of non-transport benefits to the London economy was crucial. The realisation that Crossrail created real additional outputs 'agglomeration benefits' - and that gridlock on the system would happen without it was central to this'.

While the DfT was an interested party through its agency the SRA, which co-owned the project company CLRL with TfL, Crossrail lacked a clear champion at central government level until Darling moved from the Treasury to the DfT. In his previous role he was reported to have been firmly against the project on cost grounds but then seemingly warmed to the proposal when the potential for alternative funding became apparent.

Also key to moving the project forward in the early years was London First. At that time London was already enjoying the benefit of several years of growth on the back of financial and commercial services. The chronic under-investment in the London Underground rail network was being addressed through a publicprivate partnership (PPP) programme but London First was a very active and vocal voice in advocating that continued growth would only be sustained with a major step change investment along the lines of Crossrail. Crucially, London First also formed a very influential voice back into the business community by making the case that business would need to step up and make a contribution if the project were to go ahead.

'The effort made to engage with stakeholders before 2007 was very important. The alliance of a Labour mayor and London business community proposing a supplement to the existing business rate, effectively a hypothecated tax, was compelling', said Julian Ware, senior principal of commercial finance, TfL.

\section{Business case and investment model}

Making the case for Crossrail progressed on two fronts: GLA/TfL's analysis of London's development, which projected significant growth in both population and jobs, and the high potential to develop London's service sector - already the most productive in the UK. GLA/TfL argued that London was more 
productive for a variety of reasons. Distinctive, high value industries enable London's employers to attract people with high levels of skills and education, but other factors were important in making London successful.

For example, the services industries in London were productive due to close clustering, access to wide labour markets was an important determinant to employers' willingness to locate in central London, and access to housing was essential to widen and deepen labour markets. GLA/TfL's case demonstrated the ability and fit of Crossrail both to serve that growth and relieve other bottlenecks.

Although by 2003 a 'benchmark scheme' had established the basis of the east-west railway under the centre of London, the scale and extent of Crossrail to the east and west of the central area was the subject of intense debate. Concerns over affordability and the demand of funds over time meant that all opportunities to reduce the cost and improve the value for money had to be explored.

The review of options was informed by the development of an investment model constructed to illustrate the effect of phasing or staging respective parts of the project relative to one another and over time. While the model was high level and based only on the relatively early stage cost data available at the time, the resultant scenario testing enabled the scale and pace of the project to be judged against a range of affordability profiles.

As a result of the options appraisal, the Crossrail scheme took on a very different shape, with the south-west branch being abandoned and the south-east branch ending at Abbey Wood to reduce costs while the western branch was extended to serve Maidenhead, providing significant additional benefits at relatively low cost (Figure 2). Options to phase or stage the separate elements of the project did not prove of value and were not adopted. More detail on the appraisal process and results can be found in a separate paper (Bennett, 2017).

\subsection{Learning point}

Understanding and modelling the impact of different options on cost and the timing of funding enabled CLRL to test the 'benchmark scheme' and inform the selection of a more affordable solution.

\section{Cost estimate and risk analysis}

As with any project, the cost estimate for Crossrail evolved with the development of the scheme. A significant challenge for CLRL was to maintain alignment between the engineering development and the cost estimate as aspects of the project progressed at different rates. The approach to estimation of costs also had to evolve over time, with global and elemental provisions being developed into more refined estimates as the design developed into more measureable detail.

However, it is important to note that at an early stage, any cost estimate can only be an approximation based on the information that is known at the time. Given the complexity of Crossrail there were aspects in which the areas of uncertainty exceeded the elements that could be determined and measured. The areas of uncertainty were evaluated in a risk model to produce a probability based forecast of overall cost.

\subsection{Learning point}

An approach which worked well at this stage was to avoid too much complexity too soon. Suggestions to adopt tools from elsewhere were resisted in favour of simple models tailored to address only the specific issues needed at that time. So, for example, the investment model comprised simple Excel spreadsheets while the risk model worked on approximately 200 items. Accordingly, the results produced by the respective models could be easily validated and errors recognised and corrected.

\section{Funding and finance mechanisms}

To distinguish between the terms 'funding' and 'finance', 'funding' is used in the sense of money that is available to use at the time of the expenditure, that is during the course of the project - typically this is a government grant that does not have to be paid back or serviced thereafter. 'Finance' is used when money has to be raised or borrowed and ultimately paid back through some form of debt mechanism.

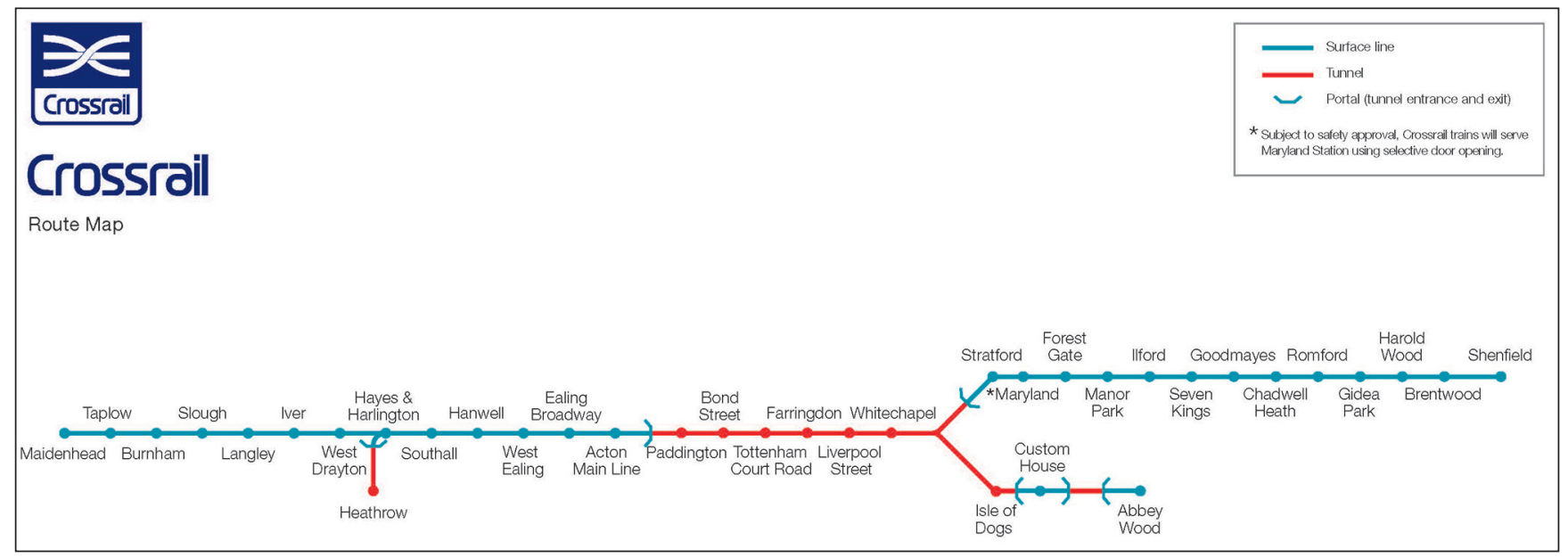

Figure 2. Bill route 
The Crossrail Review had expressed doubt that a privately financed proposition could be supported in the market but pointed to business interests being ready to contribute through 'alternative funding mechanisms'.

DfT had identified grant funds of approximately $£ 5$ billion for Crossrail, and GLA and TfL had identified approximately $£ 2$ billion that could be made available through borrowing against future revenue income (that is fares) and by reprioritising other aspects of its capital investment programme - this left a very substantial funding gap. The government had said that the scheme would only proceed with a substantial contribution from those who would benefit most from it.

How and in what form would that contribution be secured and made available to the project? While funding infrastructure through a combination of costs on direct users (i.e. fares) and through general taxation (i.e. grants) was common place, tapping the indirect beneficiaries on anything like the scale proposed had not been done before.

\section{Managing cost}

In 2004 the gap between the cost of the project - around $£ 17$ billion - and the funds available from the sponsors was between $£ 8$ billion and $£ 10$ billion. The first target for CLRL was to seek to reduce that gap through cost savings or value engineering and to assure all stakeholders that the cost estimates were confident and robust. Through a critical review of the operational requirements and further development of the design, savings of $£ 2$ billion in cost and risk reductions were identified.

\subsection{Learning points}

At this early stage, the involvement of operationally experienced staff enabled aspects of the engineering to be challenged and in some cases eliminated. For example, the base scheme incorporated two crossovers in each direction within the underground tunnelled section of the railway. Crossovers enable trains to move from one track to the opposite track but these are hugely complex structures to construct, with significant risk in engineering, cost and time terms.

The operating team determined that, in practice, there were few if any scenarios in which the train service would be re-routed by means of the opposite track and the number of crossovers was reduced to one in each direction. Similarly, the operator challenged the complexity of the tunnel ventilation system and led the process to secure agreement of the respective authorities to a reduced number of shafts along the tunnelled route.

Also, it should be expected that the cost estimate will start high when budgetary and provisional estimates reflect the immature level of knowledge of both the work required and the risk associated. Over time the costs - along with uncertainty - should reduce as the early estimates are replaced by more empirical 'bottom up' cost estimates with improved judgement around the probability and impact of risk. If early contingency provisions are not rigorous, costs may rise.

\section{Beneficiaries: business community}

Identifying the beneficiaries was informed by the work previously discussed in Section 6. The business case analysis illustrated the transformative value of Crossrail to the business community through both improved access for existing staff and access to an additional 1.5 million people brought within a 45 minute commute of central London.

Improved access was expected to produce a step-change through the clustering agglomeration effects, now recognised as key drivers in productivity and development, by driving traffic towards cluster sites. For retail businesses, there would be the added value of improved access for customers travelling into central London and the West End.

Early estimates indicated that the potential for business contributions could be $£ 2-3$ billion but collecting sums of that scale would not be achieved through voluntary contributions. To engage the business community GLA and TfL worked with London First to host a series of meetings and workshops to test sentiment and rally support. Key at that stage was the strong government message that, without a significant contribution from London business, the project would not happen. Early dialogue established the need for contributions to be equitable and fair.

The GLA's preferred mechanism was to levy an incremental supplement through the national non-domestic rate (i.e. business rates) - to be known as business rate supplement (BRS). A number of hurdles were overcome, the levy needed primary legislation, the Treasury had to agree to its hypothecation for the Crossrail project, and BRS itself would be levied by the mayor and the GLA. Following the legislation being passed and a consultation process in the latter part of 2009, the GLA published the proposed arrangements in a final prospectus issued in January 2010 (GLA, 2010) (Figure 3).

In April 2010, the mayor of London levied a $£ 0.02$ supplement on business rates for properties of a rateable value over $£ 55000$ per annum, with this threshold ensuring that smaller premises were exempt and the burden would fall on the larger businesses which were more able to absorb the cost, and most of which were along the line of the proposed route in any case. The BRS generates around $£ 225$ million per annum, which for the GLA could support borrowing of around $£ 3.5$ billion. The levy is expected to fall away once the bonds are fully repaid, which is forecast to be in the 2030s.

\subsection{Learning point}

The mayor's adoption of BRS was not an insubstantial risk. Besides the attendant political risk of imposing a levy across the city region, the mayor had to determine the rate to be applied, ensure the collection and underwrite the subsequent bond letting process to meet the funding commitments to the project.

The attractiveness of the BRS was that, as a supplement to an existing taxation base, it was easily levied and collected, and the proceeds were very predictable - the income realised has slightly exceeded TfL's forecasts. This predictability also made it relatively easy to raise capital to be repaid through its proceeds.

\section{Beneficiaries: property developers}

Property developers, both existing and prospective, stood to gain substantially from the proximity of their land and buildings to the new railway. Particular among these were Canary Wharf Group, the owners of the Canary Wharf estate in Docklands, and Berkeley Group, owners of the Woolwich Arsenal estate in Woolwich 
Civil Engineering

Volume 170 Issue CE6
Crossrail project: finance, funding and value capture for London's new Elizabeth line Buck

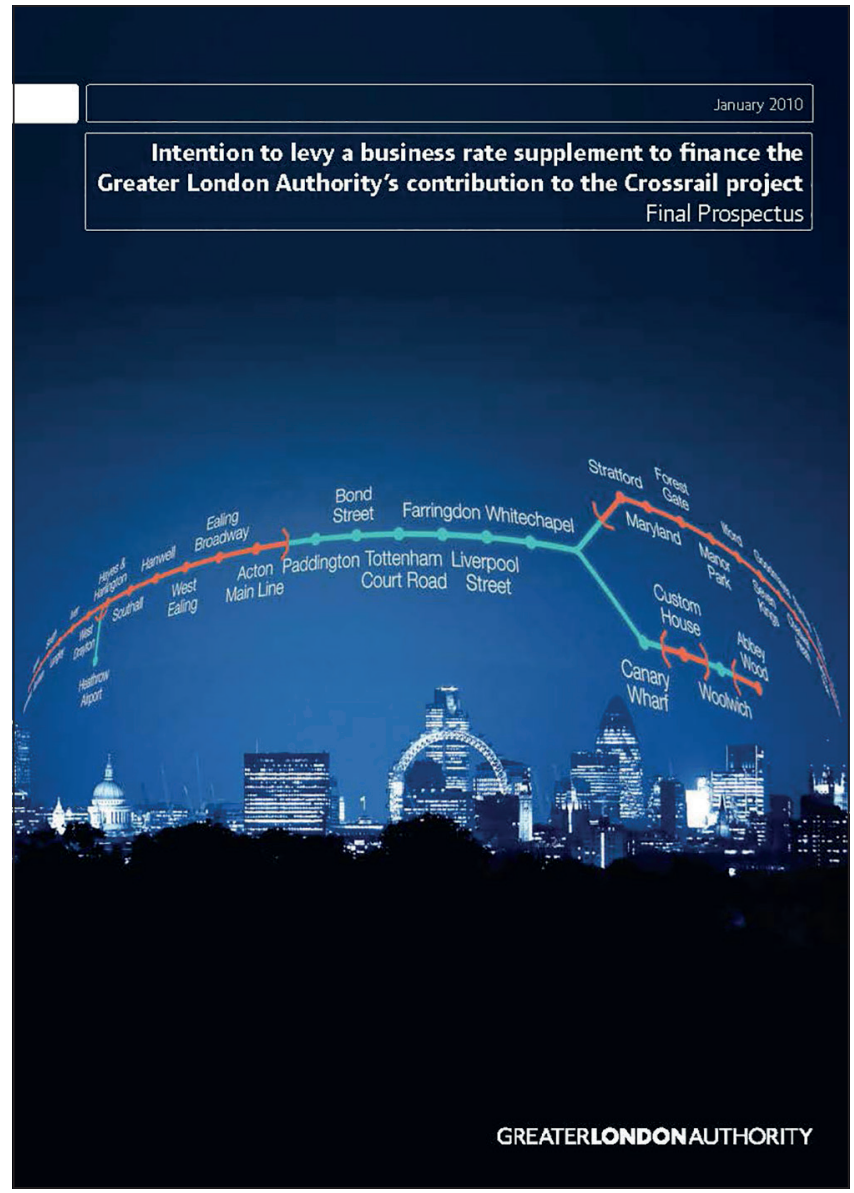

Figure 3. Business rate supplement prospectus

(Figure 4), both of which would experience substantial uplift in the development potential as a result of the railway.

The Canary Wharf Group were early movers lobbying strongly for Crossrail to be built and agreeing first to build the proposed station at Canary Wharf, and also to make a contribution of $£ 150$ million towards the cost. In return, government granted rights for Canary Wharf Group to develop retail and leisure above the station (Figure 5).

Siting a station at Woolwich had originally been rejected on the grounds of cost, inability to provide for freight trains to use the tunnel under the Thames to North Woolwich, and its potential to cannibalise the traffic generated by the recently completed extension of the Docklands Light Railway to Woolwich.

When the House of Commons hybrid Bill select committee instructed the promoter to provide a station at Woolwich, the Berkeley Group - in the partially developed estate where a station would be sited - and the London Borough of Greenwich collaborated with CLRL to make a proposal to government to construct the station. Initially, the agreement provided for the construction of a station box which would support a residential development above. A subsequent agreement provided for the cost of fitting out the station to be met between the developer and the sponsors.

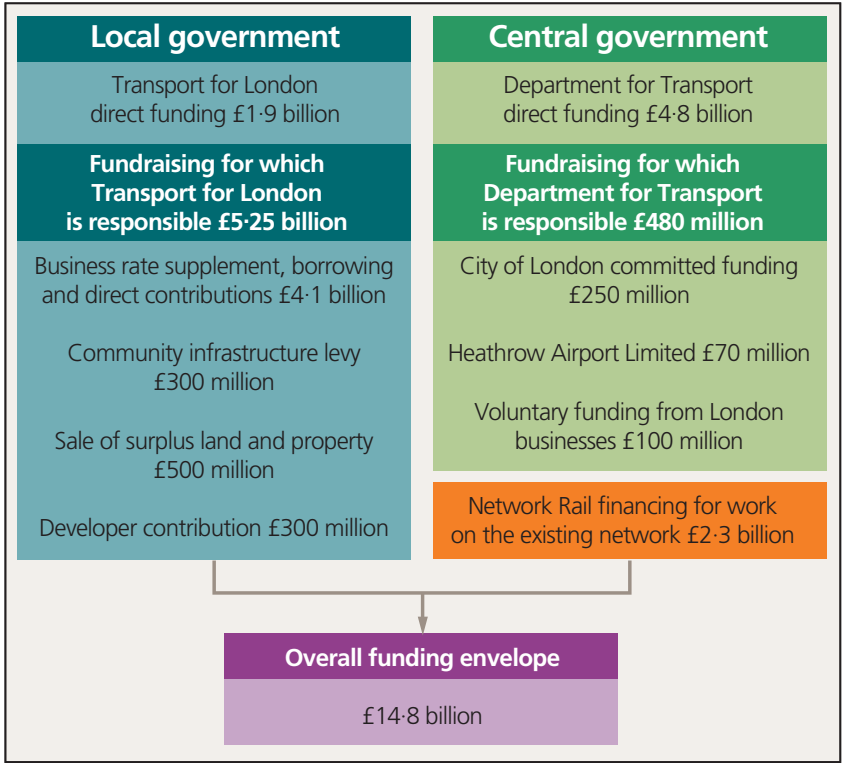

Figure 4. Final sources of funding

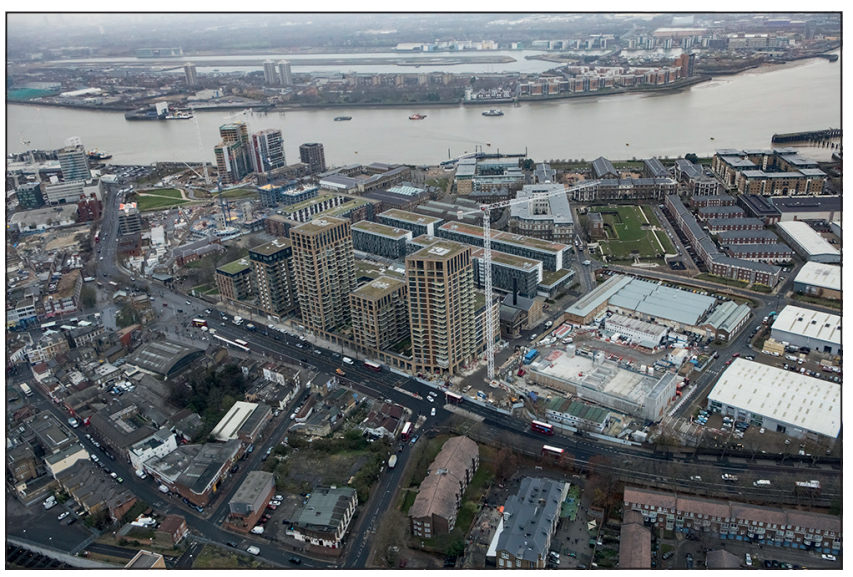

Figure 5. Aerial view of Woolwich Station with Berkeley Homes oversite developments

\subsection{Learning point}

In both of the above cases the risk to both the project and the developers was significant. The developer was investing substantial sums of money and effort into constructing a railway station that was not going be operational for several years, while failure by the developer to meet deadlines set by the project could result in delays to the critical tunnelling and railway works. Deals of this complexity could not have been done at every station: reaching agreement on acceptable terms required both developer and project to deploy very sophisticated engineering and commercial skills, and each location should be considered on a case by case basis.

More generally, Crossrail was expected to generate development across London. Traditionally, developers seeking planning permission for significant commercial developments would enter into a section 106 agreement with the local authority, serving as 
a voluntary contribution to related social infrastructure. These are private agreements made between local authorities and developers, attached to planning permissions, that make acceptable developments that would otherwise be unacceptable in planning terms, based on that section of the Town and Country Planning Act 1990. For Crossrail, the government extended those powers in the form of a community infrastructure levy (CIL), which is a lump sum on each completed development.

The CIL provided for the mayor of London to impose an additional levy on both commercial and private residential development, which as with the BRS would be hypothecated to Crossrail. The rate applied is between $£ 20 / \mathrm{m}^{2}$ and $£ 50 / \mathrm{m}^{2}$ dependent on the area of the city, and is set at the mayor's discretion. The levy for each location is set at the time of planning consent but is only payable on completion of the development. After a slow start, the CIL was generating $£ 100$ million a year by 2015-2016.

\section{Beneficiaries: Heathrow Airport}

Public transport access is a significant factor in the continuing growth of Heathrow Airport (owned and operated by Heathrow Airport Holdings Limited (HAHL), formerly British Airports Authority (BAA)). Routing a branch from the western leg of the railway into Heathrow Airport central terminals increased the efficient use of the tunnel infrastructure constructed a decade previously by BAA and substantially improved the capacity provided by the existing Heathrow Express service.

Discussions with the Civil Aviation Authority established that a contribution by HAHL on account of the improved surface access would be admissible for inclusion in the regulated asset base (RAB). This would then enable HAHL to recover the cost through the airport landing charge. As a result, HAHL pledged a contribution of $£ 70$ million to the project.

\section{Beneficiaries: Corporation of London}

The Corporation of London pledged to contribute $£ 250$ million from organisations within the City of London.

\section{Converting benefits to cash}

An immediate problem in securing funds from beneficiaries is that the money to invest in constructing the railway is required before (in the case of Crossrail several years before) the benefits begin to be realised - and even then, perhaps only with the exception of a property disposal, the benefit is accrued over a long period of time.

Not only would appropriate ways of collecting funds be needed but a method would need to be found to convert the likely longterm revenue stream into usable project funding. TfL analysis drew on international experience of raising debt for public infrastructure, with a US-style tax incremental financing (TIF), typically bonds which carry the risk of actual incremental tax receipts, emerging as a strong option.

The GLA's and TfL's balance sheet capacity and relatively low level of borrowing enabled the mayor to provide substantial support to Crossrail. GLA raised funding against the projected income generated through the BRS and the CIL. The GLA and TfL credit rating of $\mathrm{AA}+$ enabled funds to be secured at very attractive rates of interest compared to TIF or other project finance instruments because the income was much more secure.

Irrespective of the Crossrail programme, TfL had itself been granted wider powers to raise debt independently of the central exchequer and an $\mathrm{AA}+$ credit rating gave it access to very attractive funding (TfL had already established lines of bond credit with the European Investment Bank). TfL evaluated the options and rejected the TIF option electing itself to absorb the risk of the BRS receipts and retain the margin over the cheaper bond finance. Through a series of bond issues TfL has raised $£ 3.5$ billion of debt with an initial tenure of 15 years repayment.

Bringing all of the different sources together illustrates that London, in the form of business and property receipts, is contributing approximately a third of the cost of the project.

\subsection{Learning point}

While the different methods of value capture have produced a large contribution to the cost of the project, the requirement to turn future receipts into usable funds for the project required TfL's substantial corporate standing to underwrite the income and secure the debt on acceptable terms.

\section{Other funding: redevelopment over stations}

The railway incorporates the construction of nine new stations, a number of which required the acquisition of substantial property to enable the construction works to take place. The parliamentary powers for Crossrail had to incorporate provisions for compulsory purchase of the required property so that they could be demolished for the construction of the stations and respective entrance facilities.

CLRL worked with the respective stakeholders to ameliorate some of the concern around the compulsory purchase arrangements through offering to collaborate over the subsequent redevelopment of the sites (Figure 6).

\subsection{Learning point}

By adopting a collaborative approach with the existing property owners CLRL removed much of the potential resistance to the compulsory purchase process and gained the benefit of the specialist redevelopment skills of the existing owners. A separate paper in Crossrail Learning Legacy will describe the collaborative arrangement Crossrail put in place with the developers.

The redevelopment value was estimated at $£ 550$ million, which the mayor underwrote as part of TfL's contribution to Crossrail's funding package. A study commissioned by delivery company Crossrail Limited (CRL) - which replaced CLRL in 2007 estimated the uplift in land values within $1 \mathrm{~km}$ of Crossrail stations between 2010 and 2020 (the railway opens in 2018) to be $£ 5.5$ billion (Crossrail, 2012). While this is a very positive reinforcement of the case for constructing Crossrail, the estimate illustrates the very low level of value captured (approximately $10 \%$ in this case) by the public sector - the remaining $90 \%$ accruing as windfall gains to the owners of the properties impacted. 
Civil Engineering

Volume 170 Issue CE6
Crossrail project: finance, funding and value capture for London's new Elizabeth line Buck

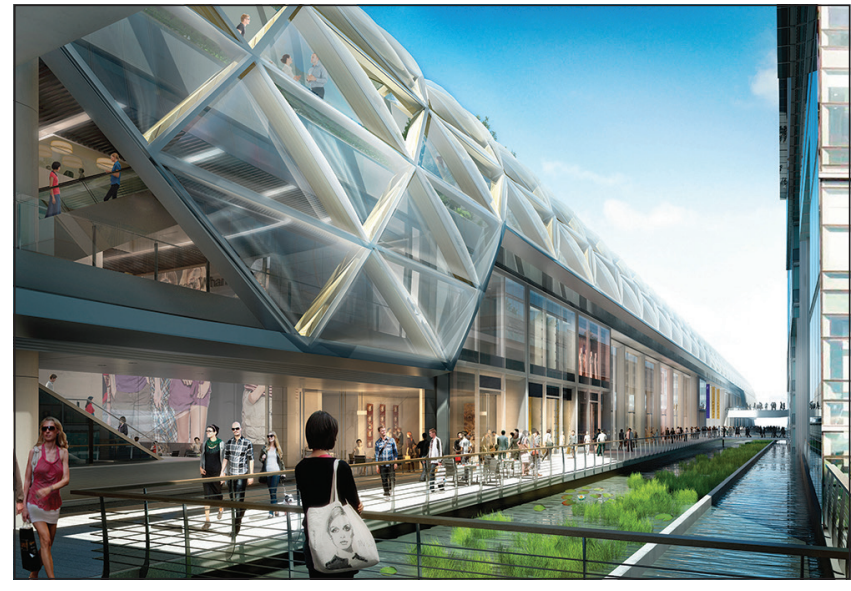

Figure 6. Canary Wharf Station oversite development by Canary Wharf Group

\section{Other funding: Network Rail}

When the Elizabeth line is fully operational in 2019, nearly $100 \mathrm{~km}$ of the total $118 \mathrm{~km}$ route length will run over tracks on the existing national railway, controlled by Network Rail. In the early 2000s Network Rail was rebuilding itself after the failure of its predecessor Railtrack, and its stated priorities were elsewhere in completing the West Coast main line upgrade and Thameslink - a similar railway to Crossrail but substantially upgrading an existing route running north-south across London. In view of its other strategic priorities, Network Rail declined to take a lead role in the project but committed to collaborate with CRL to ensure the necessary measures were put in place.

As part of the arrangements for constructing the railway the sponsors applied for a track access option, a process under the national railway regulatory process providing for Network Rail to put in place the necessary infrastructure to support a future service - this was an essential requirement to secure the commitment to the investment in the central section.

The other limb of the arrangement with Network Rail was a regulatory protocol approved by the Office of Rail Regulation in November 2009. The protocol provided for the $£ 2 \cdot 3$ billion cost of the works to be financed by Network Rail for later incorporation into the Network Rail RAB - in effect meaning that Crossrail would not have to finance or fund the works but Network Rail would be remunerated through a track access charge paid by the operator.

\subsection{Learning point}

The RAB-funded option was an effective way of defraying the capital cost of the required works. The operating revenues of the resultant service are forecast to be sufficient to cover the subsequent access charges, which also accrue a return for Network Rail at the regulatory rate.

Network Rail is also entitled to charge the 'carry cost' or interest on the debt arising during the construction period and before access charges start to flow - in Crossrail's case the carry cost could not be included in the amount financed by Network Rail and the interest costs fell to the project.

\section{Other funding: rolling stock and maintenance depot}

There was a well established market in the UK for train manufacturers and other finance organisations to provide trains and maintenance facilities on a service basis. While Crossrail had a number of unique characteristics on account of the tunnel alignments and length and capacity of trains, market consultation suggested that there would be a good appetite for a private finance initiative or PPP procurement.

As above, the $£ 1.5$ billion capital cost would be defrayed with the cost of the train fleet and its upkeep in service remunerated through availability payments by the operator after the start of the service (Figure 7).

\section{Passenger fares: operating surplus}

As discussed, the ability of capital elements of the cost to be met by the operator is dependent on the commercial performance of the railway after the start of services. Crossrail's funding case was assisted by the high level of expected usage and revenue.

Based on forecasts at the time, Crossrail's operating revenue would cover the cost of operating the service, the track access charges to Network Rail including repayment of the $£ 2 \cdot 3$ billion capital cost, repaying the $£ 1.3$ billion cost of the train fleet and associated maintenance and providing a further surplus in the order of $£ 1.9$ billion being applied to pay down TfL's debt. Taking this into account, it can be argued that Crossrail's future passengers will pay approximately a third of the cost of the project.

\section{Formalising funding commitments}

The various strands of the funding structure were developed in principle over the course of 2005-2006 and subsequently developed into a proposal submitted to government as part of the Treasury's

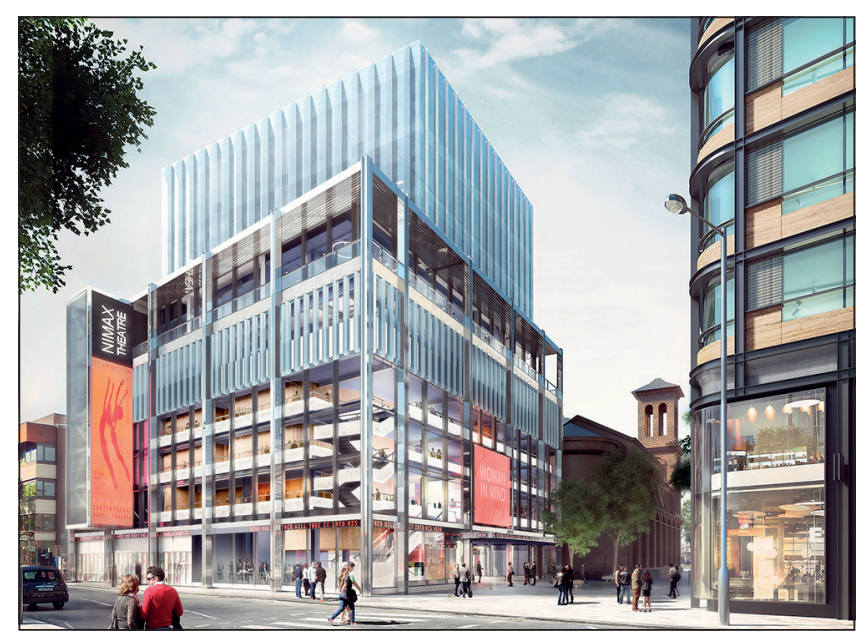

Figure 7. Tottenham Court Road Station eastern ticket hall theatre oversite development 
Civil Engineering

Volume 170 Issue CE6
Crossrail project: finance, funding and value capture for London's new Elizabeth line Buck comprehensive spending review 2007 process. During the review, CLRL's cost and risk analyses were subjected to rigorous review by both the Treasury and external consultants and were found to be robust.

On 5 October 2007 Prime Minister Gordon Brown announced a $£ 15.9$ billion package and the signing of heads of terms detailing the arrangements and sources of funding and providing for the formation of CRL as the delivery vehicle for the project. The heads of terms were developed into a suite of agreements between the sponsors, CRL and respective stakeholders. The funding arrangements between the sponsors and CRL were embedded within a project development agreement.

\section{National Audit Office review}

In January 2014 the National Audit Office published its report (NAO, 2014) on Crossrail, noting that the project had been established with an appropriate level of funding based on robust estimates, and provided certainty of funding (Figure 8).

\section{Conclusion}

At time of writing, the Elizabeth line is forecast to open on time and within its funding envelope, and London will soon start to enjoy the full benefit of a huge investment.

This success has only been possible through an innovative approach to funding, finance and value capture.

In 2003 the Crossrail Review endorsed the cost estimates, which it considered to be value for money, but expressed 'doubts about the available market capacity in the construction and finance sectors to support a project of this size' (Montague, 2004: p. 2). In its response, the government in turn expressed support for the project but noted the funding challenge saying that 'those who benefit ... should contribute substantially to its delivery' (Hansard, 2004: col. 24WS).

London's municipal and transport authorities, bolstered by the creation of the GLA and the new mayor, developed a persuasive and commercial case for investment by the business community in the transport infrastructure in the city. Working with London First, the mayor introduced a supplementary business rate with proceeds ring-fenced to fund Crossrail.

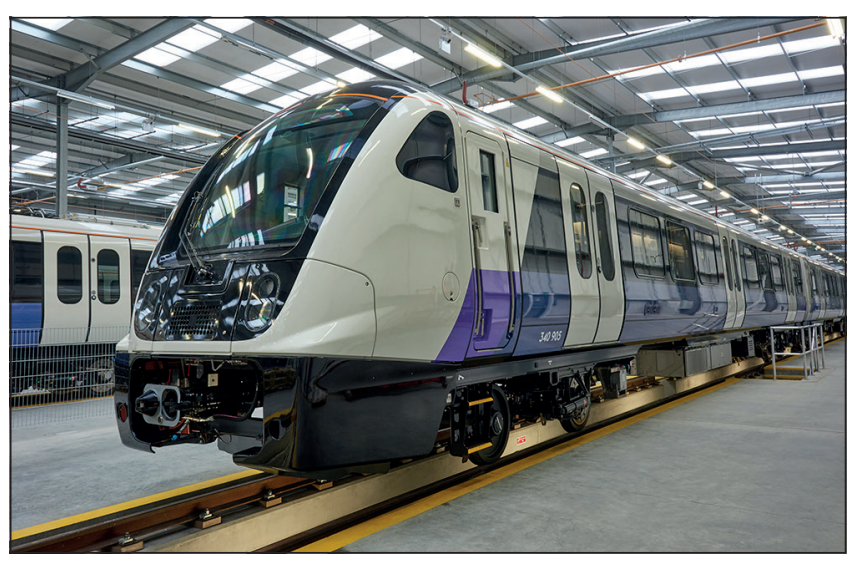

Figure 8. Class 345 train at Bombardier factory
Property development above and around station sites contributed both directly to the cost of the project and indirectly through a special ring-fenced levy applied across the city.

The forecast passenger numbers together with London's relatively high fare structure means that the future revenue income will pay for operating the railway and allow certain capital costs to be defrayed into the operating phase of the railway's life cycle. Future passenger revenues will meet the cost of upgrading the existing national rail lines, meet the cost of the new trains and the associated maintenance and provide a further surplus to repay TfL's debt.

In 2003, with access to central taxpayer funding closed off, the funding gap looked daunting - tapping indirect beneficiaries on such a scale had never been attempted before. Through a series of separate but coherent measures, London was able to engage and persuade the business community of both the necessity and the value of the investment in the transport infrastructure.

The project proceeded and London will soon start to reap its return on investment.

\section{Acknowledgements}

The author is very grateful for the assistance of Mark Fell, legal director and company secretary, and Simon Adams, head of commercial, Crossrail Limited; Shashi Verma, CIO and director of customer experience, and Julian Ware, senior principal of commercial finance, Transport for London; Bridget Rosewell of Volterra Partners; and Mark Elsey of Ashurst.

\section{References}

Bennett S (2017) Crossrail project to deliver London's Elizabeth line: from options to parliamentary bill. Proceedings of the Institution of Civil Engineers - Civil Engineering 170(6): 3-9, http://dx.doi.org/10.1680/jcien.17.00006.

CLRL Ltd (Cross London Rail Links Limited) (2003) Crossrail Business Case. Crossrail Ltd, London, UK

Crossrail (2012) Property Impact Links. Crossrail Learning Legacy, London, UK. See http://learninglegacy.crossrail.co.uk/documents/property-impactstudy/ (accessed 06/02/2017).

Crossrail (2017) Project Initiation and Development. Crossrail Learning Legacy, London, UK. See http://learninglegacy.crossrail.co.uk/learninglegacy-themes/project-and-programme-management/business-case/ (accessed 06/02/2017).

GLA (Greater London Authority) (2010) Paying for Crossrail: Business Rate Supplement. GLA, London, UK. See https://www.london.gov.uk/what-wedo/business-and-economy/promoting-london/paying-crossrail-businessrate-supplement (accessed 06/02/2017).

Hansard (2004) HC (series 6) vol. 424, part no. 23, cols 24WS-26WS (20 Jul.). Montague A (2004) Crossrail Review. TSO, London, UK.

NAO (National Audit Office) (2014) https://www.nao.org.uk/wp-content/ uploads/2014/01/Crossrail-summary..pdf (accessed 06/02/17).

Town and Country Planning Act 1990. Chapter 8. Her Majesty's Stationery Office, London, UK.

How can you contribute?

If you would like to comment on this paper, please email up to 200 words to the editor at journals@ice.org.uk.

If you would like to write a paper of 2000 to 3500 words about your own experience in this or any related area of civil engineering, the editor will be happy to provide any help or advice you need. 